\title{
The Impact of the COVID-19 Pandemic on Public Transport Passenger Categorization Practices: The Case of the Moscow Metro*
}

\author{
Ksenia Shepetina \\ Research Assistant, Laboratory of Urban Sociology, Faculty of Urban \\ and Regional Development, HSE University \\ Address: Myasnitskaya str., 20, Moscow, Russian Federation 101000 \\ E-mail: xenia.shepetina@gmail.com
}

\begin{abstract}
The paper is concerned with the social categorizations and perception of social diversity of the Moscow Metro passengers. Drawing on the Goffman's theory, I assume that the interaction between passengers is based on categorization, which links appearance and behavior of people with their cultural expectations. The categorization allows to make interaction participants identifiable and accountable. In 2020 face masks and gloves, social distancing transformed the process of categorization having directly affected personal front of city dwellers and situational proprieties. Using the theoretical resources of Erving Goffman, Harvey Sacks, and contemporary urban researchers, I compare how passengers of Moscow Metro recognized and defined each other under the regular circumstances and during the self-isolation regime, which was enforced by the city authorities at the beginning of the COVID-19 pandemic. The study is built around three general types of "Others" that were developed as abductive notions: non-specific, specific, and stigmatized Others. I analyze how these types are situationally produced and to what extent they change when the localized interactional order undergoes significant transformations. On the one hand, this study is aimed at a detailed documentation of the unique socio-historical situation that occurred at an early stage of the pandemic. On the other hand, I use it as a "natural" breaching experiment that helps to reveal the basic elements of temporal and local specificity of the social order.
\end{abstract}

Keywords: social categorization, everyday interactions, COVID-19 pandemic, strangers, metro, public places, Erving Goffman

\section{Introduction}

Public urban places are spaces of interaction between strangers. This interaction is based on a process of categorization in which participants match each other's appearance and behavior to their cultural expectations (Goffman, 1963: 11). These expectations are related both to their already-existing experience and social knowledge and to the context and situation in which each individual interaction unfolds. This categorization makes it possible to maintain the interaction order with strangers, and it relieves its participants who are cultural and biographical strangers (Lofland, 1998) from a state of complete uncertainty.

In 2020, the COVID-19 pandemic and measures taken to prevent the spread of the virus profoundly transformed the familiar context of everyday life for citizens. As early

\footnotetext{
* The reported study was funded by RFBR according to the research project № 20-04-60535.
} 
as mid-March, more and more people in Moscow gradually started wearing masks and/ or gloves. Thus, the application of the recommended hygienic measures directly affected the personal front of the citizens. The appearance of markings in public places and the requirement to keep social distance changed the situational proprieties of everyday interactions (Goffman, 1966). The introduction of the permit regime in the Moscow Metro limited the mobility of certain categories of people. In addition, public spaces, due to the very nature of the virus, have become places of a particular danger.

All of this has led to a change in the way of the categorization of other people in public places. What were these changes, and what implications did they have for everyday interactions? I will answer these questions by analyzing the transformation of the ways of the everyday categorization of strangers in the Moscow Metro during the first wave of the pandemic. The research is based on a series of interviews with Metro passengers. I will consider which categories Moscow Metro passengers use while narrating their experiences of the co-presence with other passengers before the coronavirus pandemic and during the "self-isolation regime".

The study is based on the case of Moscow. The territorial scale of Moscow with its socioeconomic heterogeneity that is reinforced by the daily commuting from the Moscow region increases the social diversity of Metro passengers. Similar "life rhythms" of citizens due to different synchronization points, such as relatively standardized working hours, make the Moscow Metro a place of close interaction with the multicultural urban context. This context reinforces the importance of categorization practices because the heterogeneity of strangers makes passengers rely more on highlighting "typical" traits rather than on their individual ones.

The Metro remained one of the few public spaces that continued to function in Moscow during the "self-isolation regime" imposed from March 30, 2020 until June 9, 2020 (Sobyanin, 2020a). During the first wave of the coronavirus, the Metro underwent the greatest transformation compared to other public spaces. The number of its passengers decreased by $84 \%$ (Meduza ${ }^{1}$, 2020a). The social composition of its users changed because of the introduction of the mandatory digital pass system. The Metro space itself has undergone very noticeable adjustments. The introduction of new patterns of behavior, translated in audio messages and visual reminders about the necessity of social distancing and hygienic norms, has significantly transformed the previously routinized context of daily urban mobility.

Such events as pandemics are usually considered at the macro level (Moore, Gould, Keary, 2003), and researchers focus primarily on migration processes and the settlement patterns of cities and countries. Much less attention has been paid to the everyday practices of the interactions in such specific circumstances or to the problem of co-presence in public places. Rather than in social sciences and epidemiology, examples of such work are usually conducted in historical studies of cities during epidemics (McCauley, 2003; Cawood, Upton, 2013; Snowden, 2002).

1. Организация, признанная средством массовой информации, выполняющим функции иностранного агента. - Прим. ред. 
Russian studies of the COVID-19 pandemic have focused more on macro-processes to this point. The most detailed research results from the pandemic in Russia can be found in the FOM collection of articles CoronaFOM Project (Oslon, 2021), which used both quantitative and qualitative data. The journal Monitoring of Public Opinion: Economic and Social Change published an issue devoted to the formation of the pandemic's meanings in the media and social networks. However, the effect of the pandemic on the interactions between public spaces visitors, especially in public transport, has not yet been studied.

In examining changes in Metro passenger interactions, I am building on Goffman's concept of public behavior (1966) and his analysis of categorization and stigmatization practices (1963). Goffman wrote about strangers' interactions in general, highlighting the structural elements of this process, while paying less attention to the features of mutual definition of the interaction participants. In Stigma (1963), he outlines the principle of distinguishing strangers, highlighting the traits that make them stigmatized; his attention is directed primarily to the polar categories of the "normal" and the stigmatized.

In this article, I will show that his approach should be supplemented by distinguishing between several types of strangers. I develop Goffman's ideas with the approach of membership categorization analysis, offered by H. Sacks (1972a, 1972b), and complement it with relevant urban studies conducted within the framework of interactional sociology (Cresswell, 2006; Watson, 2006; Darling, Wilson, 2016; Ocejo, Tonnelat, 2014). These authors did not suggest any classifications of city-dwellers or divide them into some certain groups. However, they were focused on different particular specificities which can be considered as a foundation for such distinctions.

Drawing on this reasoning, I suggest a three-part classification of strangers: the "nonspecific other", the "specific other", and the "stigmatized other". Each of these types of strangers differs in the degree of otherness, the presence of a moral evaluation, and the principle of interaction with them. Depending on which type the stranger belongs to, the same elements of interaction cause different reactions and lead to different interaction scenarios.

All except one of the interviews used in this paper were conducted from April 15, 2020 to May 12, 2020 (before the introduction of mandatory mask-wearing) by me and my colleagues as a part of the project "Everyday Practices of Public Health: (Non-)following Sanitary Rules at Moscow Public Transport during the Coronavirus Pandemic”. I focused on this period, because during this time, people were spontaneously generating new forms of behavior in the situation of the absence of mandatory requirements formulated by the authorities.

Later in the article, I will first present a conceptual framework for analyzing everyday interactions between strangers in public places and justify the distinction between the already-mentioned three types of strangers. Then, in the empirical part, I will examine the changes in categorization practices regarding each of the three identified stranger types. 


\section{The Theoretical Framework}

Goffman's interactional sociology $(1966,1983)$, the framework with which this study is conducted, allows us to examine the categorization process in relation to the informants' everyday experiences, rather than examining only their general ideas about different groups. This makes the analysis more sensitive to the situation in which categorization occurs and allows to capture its changes. This is especially important for the period under consideration when attitudes toward the coronavirus and the decisions made to control it were in the process of (re)definition and changing because of both the spread of the pandemic and the constant extension and strengthening of measures. These measures directly affected the appearance of citizens and the rules for using public spaces, both of which serve as a foundation for categorization that enables interactions between strangers.

I complement Goffman's theory with the membership categorization analysis approach (Sacks, 1972a, 1972b) and public transport studies (Jensen, 2006; Koefoed et al., 2017; Ocejo, Tonnelat, 2014), with whose help I explain the possibility of distinguishing between the three types of strangers on the basis of the strength of the moral evaluation applied to them.

To start with, I will consider the key concepts of Goffman's approach that are used in this study in some detail. Next, I will demonstrate the specificities of everyday interactions in public transport. Finally, I will propose my classification of strangers that both complements Goffman's approach and allows for a more detailed analysis of the transformation of categorization practices in pandemic situations.

\section{Everyday Interactions in Public Places}

According to Goffman, public spaces are characterized by unfocused interaction between people and civil inattention (1966: 83). Being in a public place, people are aware about the co-presence of each other, they realize that they share space with others, and they make it clear to each other by, for example, a quick glance and keeping a distance (Ibid.: 17). Co-presence is not simply about being in the same space; it is a form of interaction in which participants of the gathering become perceived, "accessible, available, and subject to one another" (Ibid.: 22). Goffman uses the concept of situation to refer to the spatial environment in which assemblies are formed (Ibid.: 18). Situated-ness ensures the order of interactions between people, because for each place there are certain situational proprieties, that is, rules that regulate behavior.

Another notion from E. Goffman's approach that is also important for the analysis of everyday interactions is the personal front which includes everything that makes up a person's appearance. In the situation of co-presence and unfocused interaction, it represents one of the few sources of information about the participants of the gathering as well as the basis for categorization. 
In a public place, one always makes a "scan" of the space from which one receives information about the situation and the participants of the gathering, and conducts a categorization which makes them identifiable and understandable. Categorization is the process of an "ordering" by which "a potentially chaotic and meaningless world of strangers was transformed into a knowable and predictable world of strangers" (Lofland, 1985: 22). This ordering in public places consists of "appearential ordering" and "spatial ordering", the body and the place presentation of strangers which allow to identify them (27). Categorical knowledge is information about the status, the role of co-presenters, the attributes accompanying them; it indicates participants' belonging to some social groups. Categorical knowledge (e.g., information about approximate age, gender, occupation, or economic status) can be transmitted during interaction just through the gaze (Lofland J., 1969; Lofland L., 1973).

Categories contain certain criteria and expectations established in society, the conformity or nonconformity to which allows to put the stranger into an existing cultural framework. The stranger's status is either normalized or stigmatized (Goffman, 1963). Stigma is the undesirable, negative difference between the stranger and the expectations of others who, not possessing it, are considered as "normal" (Ibid: 5). A person with stigma is subjected to a moral evaluation by others, and discrimination; Goffman says "We construct a stigma-theory, an ideology to explain his inferiority and account for the danger he represents, sometimes rationalizing an animosity based on other differences, such as those of social class" (Ibid.). In relation to the stigmatized, "normal" others express disrespect.

The pandemic of COVID-19, and especially "the self-isolation regime" and the restrictions connected with it, has not only changed the demographic profile of Metro riders. It deprived the city, including public transport, of the usual hustle and bustle and crowdedness which is the essence of modern urban life. Everyday encounters and interactions with strangers have been challenged by the changed epidemiological situation. Public places have become spaces of particular danger because of the nature of the virus which can be transmitted through the air and by touch. New recommendations for Metro usage in the form of markings for distance observation, audio announcements related to the pandemic, and, afterwards, electronic passes restricting access to public transportation were introduced. All of these factors have transformed the spatial ordering.

At the same time, the pandemic has also affected the appearential ordering. For example, viruses that had previously received names associated with their place of origin, such as the Ebola virus that was named after a river in the northern Democratic Republic of Congo, led to discrimination, increased inequality, and more hostile attitudes toward migrants from the countries and regions concerned (Ferreira et al., 2020). In the case of the coronavirus pandemic in Russia, at the beginning of the first wave of coronavirus, groups of people from China were identified (Sobyanin, 2020c). Aggression against such groups, or at least increased suspicion or other changes in categorization, is especially possible because the media often use war metaphors in relation to the COVID-19 pandemic. Research shows that the pandemic can become a condition of solidarity even 
among strangers when the desire to follow the rules is equated with concern for others (Will, 2020; Matthewman, Huppatz, 2020). Meanwhile, there are some stable social rituals, such as greetings, which, despite their risks in the context of the pandemic, remain important normative everyday practices (Mondada, 2020).

Goffman's approach was developed and supplemented in the works of H. Sacks who elaborated membership categorization analysis (MCA) (1972a, 1972b). MCA deals with the collections of categories, the application of which is controlled by certain rules. In identifying these collections and rules, researchers emphasize the importance of the normative nature of categorization. Depending on the conformity or nonconformity of interaction participants with expectations based on the categories attributed to them, they receive a moral evaluation (Jayyusi, 1984, 1991). In addition to actions fitting certain categories, MCA also identifies a wide range of predicates associated with different categories (Watson, 1978); however, both these and normative expectations are immersed in the contexts of individual situations. The work in MCA is notable not only for its particular way of dealing with data, but also for its greater attention to broader and more pervasive categories related, for example, to gender (Stokoe, 2010; McKinlay, McVittie, 2011) or ethnicity (Markaki, Mondada, 2012; Kahlin, Tykesson 2015).

Following the researchers in MCA, I refer not only to stigmatized categories, but also to those who are perceived as "normal", that is, those who do not attract much attention to themselves. I call this type of passenger "non-specific others". In doing so, I emphasize that categorization is not a process of singling out the exceptional and unaccustomed, but the basis of any everyday interaction between strangers.

Goffman's approach, supplemented by the ideas of his followers, helps me to identify the main dimensions within which the categorization of strangers occurs, those of personal front and situational propriety. This allows me to identify how categorization changes in the pandemic and what is more significant in this relation in interactions with strangers, their appearance or their behavior.

\section{Public Transportation as a Space for Everyday Interactions}

Public transportation is not only a tool for everyday mobility, but also an important public space in which urban life is (re)produced. Researchers consider it as a place where an urban community (Lucas, 2006; Welch, Mishra, 2013; Ingvardson, Nielsen, 2019) and the emotional background of urban life (Zaporozhets, 2014; Davis, Levine, 1967) are formed. Public transportation, as a space of strict regulation and control (Bærenholdt, 2013) and sometimes social exclusion (Bissell, 2016; Sager, 2016), acts as one of the fundamental means of constructing contemporary urban order and safety (Augé, 1995, 2002). As cities grow, the proportion of time a citizen spends on public transportation only increases (Lindelöw, 2018; Banister, 2011), which suggests that the experience of using public transportation is increasing in importance. All this points to the multifaceted role of the experience of using public transportation in the construction of the image of urban life. 
The particular context of public transportation is the ever-changing flow of very different and unfamiliar passengers forced into close bodily co-presence (Maines, 1979; Anderson, 2004; Adey et al., 2012). In addition, Metro passengers often have no way of guessing in advance who exactly they might encounter on the train because of its scale (Ocejo, Tonnelat, 2014). Each new stop of the Metro train brings new strangers who enter and exit the car. That said, public transportation is also a space where opposites collide. Other public spaces often lack this level of uncertainty and heterogeneity. This further reinforces the importance of categorization practices because the heterogeneity of strangers makes passengers rely more on highlighting "typical" features rather than on their individual traits.

Such features of public transport only reinforce the need to structure the passenger flow by singling out passenger types differing from each other by the degree of sociocultural differences. It is even more important to study this in a comparative perspective, that is, analyzing the conditions for which have been created by the coronavirus pandemic. This allows to identify the most stable and the least stable categories of passengers according to the level and grounds of their moral evaluation.

\section{Types of Strangers}

Goffman's approach and existing studies of everyday interactions on public transport need to be supplemented. In Goffman's case, the need for addition stems from the fact that categorization is not a process of singling out the exceptional and unfamiliar, but the basis of all everyday interactions between strangers. Therefore, some categories of strangers are perceived by participants in the interaction as "normal", not attracting much attention to themselves. As for the studies of public transport as a space of everyday interactions, their weakness is that, despite their emphasis on the multiculturalism of large cities and the frequent interactions between different people, the boundaries between them are far from always being blurred or erased. On the contrary, this can lead to an even greater segregation.

In this article, I propose to distinguish three types of strangers encountered in everyday situations, depending on the degree of cultural proximity to the person making the categorization in a public space.

The first type is the non-specific other. Non-specific others are passengers whose personal front and actions in no way distinguish them from the general passenger flow. As the city is a "world of strangers, a world populated by persons who are personally unknown to one another" (Lofland, 1985:3), such passengers are regarded just as anonymous co-presenting strangers. Despite the differences between them which are obviously present, these differences, on the one hand, are all too familiar in everyday urban life, while on the other hand, they allow to categorize strangers as being close to the social group the categorizer belongs to. Thus, while recognizing socio-cultural urban diversity but considering it as the foundation of large cities at the same time, researchers sometimes develop 
a theory of interaction between strangers, leaving aside some fundamental differences between strangers and the associated consequences for interactions (Goffman, 1966).

When only passengers of this type act as participants in an interactional situation, they appear to be grouped into certain commonalities, for example, into "workers" and/ or "students" in the morning car, but even more likely into "ordinary people", that is, men and women of different ages. In interactions, civil inattention is maintained which can only occasionally be broken by mutual involvement (e.g., passengers may give up their seat to each other or ask each other what the next Metro station is).

The second type is the specific other. Such strangers attract a little more attention than others, even though they correspond to the usual framework of the urban cultural diversity (Cresswell, 2006; Watson, 2006). If we consider the historical context, it is possible to understand who the "specific other", and later, the "stigmatized other" are by using the appearance of an "outsider" in some rather isolated communities as an example. Their presence causes a variety of intense emotions and, for example, deification or hostility and violence towards them. Nevertheless, depending on the degree of difference between the stranger and the host community, the new person can became partially understood, explained and accepted, or otherwise excluded (Lofland, 1985). The excluded one becomes stigmatized and marginalized, while the accepted outsider is only specific. Thus, "specific other" and "stigmatized other" in this work are distinguished based on the degree of their otherness which is actualized either by a comparison with the one who is categorizing them or with co-present others.

Specific others stand out from everyone else, but their cultural differences are not too significant; there are no sustained associations and expectations in public discourse that would be associated with strong negative moral judgments. For example, such people might include representatives of subcultures or of an economic status different from the categorizing one's own.

The third type is the stigmatized other (Goffman, 1963). Such passengers stand out because of the characteristics of their personal front and/or actions and are rarely overlooked (Darling, Wilson, 2016; Ocejo, Tonnelat, 2014). There are also clear negative biases associated with their image, which are only reinforced if such passengers violate situational propriety during interactions, or something draws the attention of others to their personal front. For example, a person lying on the seats is likely to be the object of prolonged judgmental stares. Goffman identifies three different types of stigmatization; on the basis of physical deviations, individual character defects, and race, nationality, or religion (1963: 4). I would like to also highlight more specific reasons for stigmatization that are specific to the context of public transport.

An important limitation of this work in singling out the "specific" and the "stigmatized" is the homogeneity established in the sample due to the limitations of recruitment in the midst of the pandemic. All of my informants can be described as a "middle class," many of whom have a higher education and full-time jobs and have lived in Moscow for a long time. In this sense, they can be grouped into one general category according to 
their socio-economic status, in relation to which they categorize others in the process of daily mobilities.

\section{Research Methodology}

The study is based on an analysis of 20 semi-structured interviews with Moscow Metro passengers who continued to use public transport during the first wave of the coronavirus in Russia. This data was collected as part of a research project of the Laboratory of Urban Sociology. The interviews were conducted from April 15, 2020, to May 13, 2020. In Moscow during this time, schoolchildren and students were put on "vacation", April was declared as "non-working" by a presidential decree, many public places were closed, and using public and private transport was possible with a digital pass only (Sobyanin, 2020a). What is even more important in the context of this work is that wearing masks and gloves on public transport became mandatory only on May 12 (Interfax, 2020). This means that the question of the necessity of following some sanitary-hygienic measures (wearing masks, gloves, or other forms) was not formally regulated in any way during the field phase of the study. Passengers worked out their own individual measures against the coronavirus.

This paper is based on the comparison of two time periods which can be roughly called "before" and "after" the beginning of the coronavirus pandemic. However, the "before" period was considered retrospectively in the interviews. Everyone had not only heard something about the coronavirus by the time of this study, but the "self-isolation regime" had already been introduced in Moscow. How did it affect the narratives about daily mobility on the Metro before the pandemic? I would argue that there is no reason to assume that these memories might have been distorted by the new experience of the pandemic. Firstly, the design of interview was aimed to strictly separate these two periods to keep a balance of focus on both. At the beginning of each interview, I asked respondents to look aside from their latest impressions for a while and concentrate on the memories of the period before the pandemic. Thereby, their narratives were not supposed to include any references to the changes that had occurred. Moreover, this distinction between the two periods was not confusing to my interviewees since comparing "before" and "after" is a common practice for analyzing shifting context. Secondly, the period "after" was not stable and by the time of conducting this research, the pandemic's impact had just started to transform the reality. The pandemic and its severity were still characterized by great uncertainty, while the image of "before" the pandemic was clearly established and familiar due to its long-term duration and relative stability.

Due to the measures taken in Moscow, I used rather clear age boundaries while forming the sample. In his address on March 23, 2020, the mayor of Moscow obliged people 65 and older to "observe the home regime" (Sobyanin, 202ob) which limited the mobility of these people. Therefore, the upper age limit for informants was 64 and the lower limit was 18 (from this age, on the one hand, full-time employment is possible, and on the other hand, parental permission is not required for interviews). Other criteria for 
constructing the sample were gender, the length of daily commutes, the combination of transport modes used by the passenger, and the destinations of Metro trips. Searching for informants, I diversified these criteria in order to get descriptions from people with different, in some cases opposite, experiences.

As a result, the sample included Moscow Metro passengers from 24 to 51 years old; fourteen of them were 24 to 34 , and six were 44 to 51 , while the gender distribution was 12 women and $8 \mathrm{men}$. With three exceptions, all of the informants continued to use public transport because they had to attend work in an offline form. At the same time, not all of them went to work every day; there were also those whose trips were reduced to once or twice a week. For all of the informants, a typical Metro ride took at least 20 minutes.

The informant recruitment took place on Facebook through the publication of an invitation post, as well as through the publication in a group dedicated to the Metro. This way of searching for informants was a forced measure due to a number of constraints, both in resources and ethically (for example, in this epidemiological situation, it was difficult to recruit directly in the Metro).

As a result, a diverse sample was constructed, including people from a wide range of professions; a designer, two engineers, a bank employee, a civil servant, a student, three medical workers, a construction worker, and others. None of the informants were acquainted with the author before the interview.

\section{Transformation of the Ways of Categorizing Metro Passengers}

\section{Non-specific Others}

Speaking about the passenger's flow before the coronavirus pandemic, the interviewees presented it firstly as a faintly discernible mass of people who were described within age and gender categories. In addition, the perception of the common purpose of using public transport in the commute to work and back also contributed to maintaining this monotonous image. Instances of violations of situational propriety by non-specific others, although they caused internal irritation on the part of passengers, did not lead to an extension of the moral assessment to any particular categories of people. It was rather individual and situational.

With the introduction of the "self-isolation regime", the crowd disappears from the Metro, but a new way of generalizing passengers emerges, that is, their consolidation into the category of "working people," which at this time, because of the decisions of the authorities, was fixed discursively. At the same time, categorization also arises due to the noticeable absence of certain categories of passengers who were not singled out before, unless they violated situational proprieties. 
PRACTICES OF CATEGORIZING NON-SPECIFIC OTHERS BEFORE THE CORONAVIRUS PANDEMIC

Before the emergence of the coronavirus, Metro users, for whom this mode of transport was a habitual part of their daily lives, perceived each other as a single stream of "ordinary" people. Passengers became part of one community of the crowd and the passenger flow, even though the composition of this community was constantly changing during the trips. The formation of such a perception is partially facilitated by the fact that the informants told me mainly about their way to and from work, which allowed them to categorize other participants in the gathering as monotonous co-present strangers:

When you transfer to Tsvetnoy Boulevard, who do you ride with in the car?

I just can't characterize them in any way, just ordinary. There are not many seniors, children, there are almost no schoolchildren. Usually, it's people who are also going to work. Some kind of office workers, which is probably the majority in Moscow.

(Woman, 48 years old)

The actions during the trip in the Metro consist of applying the transport card, choosing a place on the escalator and a seat in the car were automatized. Non-specific strangers did not arouse much interest, and interactions were limited to civil inattention and, if necessary, joint coordination of actions to avoid encounters. At the same time, due to the frequent forced close bodily presence with others, some passengers could switch to various subordinate involvements, as if avoiding focused interaction (Goffman, 1966: 44), thereby emphasizing their inattention. This allowed them to disengage from the situation, but at the same time, made them less able to discern the passengers around them. As in many other examples of public transport research, Moscow Metro passengers occupied themselves by focusing their attention on books, music on headphones, reading the news, and more (Ocejo, Tonnelat, 2014; Zaporozhets, 2016):

In general, how do you feel in such a crowded space [metro car]?

Actually, at such moment, according to my associations, I don't really feel anything, because I try to distract myself, I try to put my attention somewhere to the phone. Because there's not much pleasant at such moment, it can be crowded, it can be hot, you feel how you are sweating. It's all not very interesting to experience and unpleasant.

(Man, 29 years old)

However, when trying to reconstruct who these "ordinary" people are, several grounds for categorizing and distinguishing emerged. First of all, strangers who did not violate situational proprieties were divided into "simple" categories (e.g., gender, age) (Lofland, 1973) for whose identification on a personal front alone is often sufficient. Ethnically different ${ }^{2}$ passengers who did not violate situational proprieties, despite cultural differences,

2. By ethnically different passengers, I refer to those who are identified as such in any particular context. Of course, any passenger who identifies himself as ethnically different will not automatically be identified as such by other passengers, and not all of such identification from the outside will cause any specific attention. 
were not perceived as specific others attracting special attention. They may well have blended in with the rest of the gathering, especially in a crowded car since their presence on the Metro is quite familiar.

When people were singled out only by their actions and their personal front provided no additional information about the gathering participants, they remained co-present strangers, but violating the rule of taking others present into account. In the first place, their singling out had to do with closeness, not simply with the experience of close bodily co-presence of the passengers which is absolutely routine for them, but with the fact that the passengers are forced to become part of the life-world of the other.

\section{PRACTICES OF CATEGORIZING NON-SPECIFIC OTHERS DURING THE "SELF-ISOLATION REGIME"}

During the period of self-isolation, the Metro ceased to be a place of large crowds of people. The reason for this was the emergence of a new formal condition with the introduction of the "self-isolation regime", and the need to obtain a pass to travel on public transport. This also led to changes in categorization practices. Despite the fact that everyone had the right to get a pass twice a week during the period of self-isolation, Metro passengers now had a new basis for categorizing others as a single community, that of working people:

Currently, employees of continuous production, medics, pharmacists, sellers remained [in the metro]. People who are related to medicine, like me. <. . > Mainly, in public transport people are keeping social distance and don't communicate with each other. It is clear that they are going on business.

(Woman, 28 years old)

This is most likely since the majority of informants themselves continued to use the Metro specifically for commuting. Nevertheless, both official measures and the passengers' self-organization in following sanitary and hygienic norms made Metro users more homogeneous in the informants' perception.

The informants also believed that due to this homogenization, Metro passengers were more diligent and coherent in following sanitary and hygienic norms than others. This pattern emerged when I asked informants about other public places they currently visit. Most often, they compared the behavior of people in the Metro to that of visitors to stores, where, in their opinion, the diversity of visitor categories had not changed;

It seems to me that there is more discipline in public transport. Perhaps, it's because there's a specific generation of people using it, who goes to work more frequently, they are more aware of the current events. In the stores, we have a bedroom district, we have a lot of senior people, I think they are putting less efforts [to act according to the rules].

(Woman, 48 years old) 
Thus, with the introduction of the "self-isolation regime," generalized, non-specific Metro passengers become more concrete. The weakly-discernible passenger flow is replaced by a category of working people who are fixed discursively because of the introduction of the permit regime. There are expectations of discipline and awareness in relation to them; this category is not distinguished between different Metro passengers as it was in normal times, but between passengers and visitors to other urban public spaces.

A new principle of categorization emerged in the description of co-present strangers in the Metro, that of the highlighting of absent categories. At the same time, informants did not take into account the fact that, as mentioned above, even during digital passes, anyone could make it several times a week:

There are no little children in public transport at all. It's a relief. $<\ldots$. > There are, mainly, middle-aged people. And visually, there are no longer those who travel in groups or in pairs.

(Woman, 28 years old)

This can also be explained by the fact that these categories of people were primarily excluded from the Metro space discursively. For example, such a category were those passengers over the age of 65 who were advised by the mayor of Moscow to stay at home even before the introduction of electronic passes. Another category is the schoolchildren who were transferred to distance learning, and their transport cards were suspended. In this way, some of the Metro riders to whom other passengers did not pay special attention in normal times by lumping them into the general mass of unspecific others became visible. Next, I will show how the perception of these categories changed when they became transgressors of situational proprieties.

\section{Specific Others}

Before the COVID-19 pandemic, the type "specific others" included passengers who stood out from the general background both because of their personal front and their violation of situational proprieties. The peculiarities of the personal front of such passengers often indicated their low socio-economic status, but they can also be assigned to specific cultural communities. Although such strangers attracted increased attention to themselves compared to non-specific others, passengers are willing to ignore their otherness if the rule of civil inattention is not violated, and do not engage in focused interaction with them. This is because such strangers are not perceived as unambiguous troublemakers; there are some expectations associated with them, but no clear preconceptions. Even if they are subjected to moral evaluation, other passengers are less critical of them, distinguishing them from stigmatized others.

During the "self-isolation regime", specific others practically disappear from the informants' narratives. According to their perception, the composition of Metro passengers became more homogeneous. During this period, the division of passengers into socio- 
economic categories ceased to be significant, and the categorization of strangers according to their adherence to new sanitary and hygienic recommendations came to the fore.

\section{PRACTICES OF CATEGORIZING SPECIFIC OTHERS BEFORE THE CORONAVIRUS} PANDEMIC

Specific others include passengers who violate situational proprieties. At the same time, the categorization of these people is also based on the simultaneous identification of features in their personal front that connect them with particular categories.

As has been shown earlier, people who violate situational proprieties, whose personal front is associated only with "simple", broad categories of gender or age (e.g., the generalized middle-aged woman) remain only non-specific strangers to others. They do not elicit a moral evaluation because the category to which they can be assigned is too broad and is perceived by others as "normal" (Goffman, 1963: 5). If it can be supplemented, for example, by an indication of socio-economic status or by linking it to some cultural traits, such passengers become specific others:

\section{Who can get your attention?}

Well, everyone's favorite category is "metro-babki" [old women in the Metro], of course. These are grannies, it is not clear what they do in the Metro at 8 in the morning with their carts. Despite the fact that they look rather weak due to age and health, they are able to cram you into the fullest car, and then reproachfully breathe down someone's neck, showing they want to sit down.

(Woman, 27 years old)

The categorization of these people is based on two criteria: what a person does and how she looks. This quote aptly describes the main ways in which order is violated in the Metro: in the case of forcing a focused interaction, like an elderly woman who "asks" to give up the seat to her by hovering over a passenger without saying anything. The figure of the elderly person here is supplemented by the location in space and time and features of the personal front, in this case, the presence of a cart. Thus, specific others are not older people in general, but only those who have these attributes, which, according to the informant, put them in the category of "Metro grannies".

At the same time, it is with respect to these categories of people that the discourse enshrines attitudes about the rules of interaction with them: younger passengers need to give up their place to their elders and treat them with respect. This explanation is based not on her direct experience of interaction with elders or on the peculiarities of their status as passengers, but on the general ideas about the rules of interaction with these older women. In this regard, passengers make arguments that either normalize and justify the behavior of such categories of passengers, or explain the necessity of non-interference.

The singling out of specific others can also be based on a personal front alone. Turning to the experience of using the Metro in the pre-quarantine time, we can identify several characteristics that indicate class, status differences of passengers like smell, their state of 
dress, or facial expression. At the same time, some cultural features can be combined with these characteristics or stand alone. For example, people with a bright appearance, in unusual clothing, or even themed costumes are not ignored in the Metro. These criteria by which strangers are categorized in the Metro reflect the characteristics of not just public transportation, but the cultural diversity of the city as a whole (Watson, 2006). Against the general background of strangers, the holders of a particularly prominent status or cultural differences are categorized as specific others.

Specific others, who are defined primarily by their personal front, turn out to be "workers" in the Metro, and passengers categorize them by their dirty, dusty, sometimes sports clothing. Their personal front is contrasted with office workers, who ride the Metro in formal suits and are categorized as non-specific others.

This type of strangers also includes passengers from the regions because of the combination of socio-economic and cultural features in their personal front. According to informants, passengers on regional electric trains and, more recently, the MCD, are very different from Metro users:

There are more average women in trains. In the Metro I more often see more welldressed women, very stylish, with a good make-up. Not just casual clothes, but with chosen with some sense.

(Woman, 28 years old)

[S] ometimes it happened that you sit in front of a woman, she's sleeping, an ordinary tired woman. Then you open your eyes near Moscow, and she's putting on makeup. <. . > In short, she washed her face and put on makeup, and by Moscow the klushka [clumsy woman] turned into a tsarina, korolevishna [queen], and starts walking ... In the Metro, there's nothing like this, the public is homogeneous, you don't have such a shock that you open your eyes and there's a person in front of you with blue eyeshadow makeup on, you wouldn't see that.

(Woman, 31 years old)

They, like the workers, are contrasted with the non-specific Metro passengers dressed tastefully. Additionally, Moscow-region passengers are sometimes singled out by informants because they are not dressed according to the weather: they often wear warmer clothes than others.

Singling out these two categories of passengers as workers or commuters from the regions indicate the informants' perceptions of class and territorial inequality and their attendant attributes such as a display of impurity, leading to an exclusion from the actual definition of taste in relation to clothing choices. In the perception of Metro users, these passengers are not simply different from others by their economic status, they are also ascribed special cultural attributes. Whatever the case, there are no negative moral evaluations in relation to these categories.

Another category of passengers that involves a certain combination of the characteristics of personal front and (non-)adherence to situational proprieties is "commuters from 
the regions". These are people who make assembly participants uncomfortable because of their inability to conform to the rules of spatial coordination and safety in large cities and, in particular, in the Metro:

\begin{abstract}
How do you understand that they are visitors?
By the frightened eyes, by the panicked actions, by the way they are standing. People are facing the exit, going to get out, but they are standing with their backs to the exit. $<\ldots>$ Sometimes it happens that they are carried out while they still resist, try not to get out, they are terrified of it.
\end{abstract}

(Woman, 48 years old)

The lack of knowledge and skills in using the Metro makes newcomers not quite fullfledged passengers, and sometimes even leads to their objectification: in the quote above, non-resident passengers are described not as full participants in the gathering, but rather as a material obstacle that more experienced passengers are forced to overcome. Often, a spatial marker is added to such people; they are expected to be met most often at the ring stations and stations near a railway. At the same time, their presence in the Metro is common and acceptable because their appearance can be predicted. Such passengers do not become stigmatized by others, despite socioeconomic and cultural differences and their inability to use the infrastructure.

Even those signs that indicate inequality and cultural differences (e.g., the appearance of workers) are rarely reflected in the interactions between gathering participants if they involve violations of situational proprieties. The basic principles in the Metro are still the maintenance of civil inattention and the avoidance of focused interaction.

\title{
PRACTICES OF CATEGORIZING SPECIFIC OTHERS DURING THE “SELF-ISOLATION REGIME"
}

With the "self-isolation regime", the division of people in the Metro into residents of Moscow, the Moscow region, and commuters from other regions disappeared. Singling out specific others by indicating cultural differences or a special socioeconomic status became rare when describing other passengers. For some people, specific others were overshadowed by the virus and sanitary measures; for others, specific others disappeared because it became difficult to see any details under their masks.

Since the beginning of the spread of the virus, masks as a new, unaccustomed detail of the personal front of strangers in the Metro have captured the attention of passengers. For those who had not yet begun to use them, they symbolized the need to make a decision for themselves on this issue. In addition, at that time there was a lot of discussion in the media around the necessity or, conversely, the danger of using masks (Meduza, 2020b). Opinions on the necessity of these means were divided, and with it, the two categories of Metro users became the masked and/or gloved and the unmasked.

My informants had very different attitudes toward masks: at the time of the interviews, some had been using them for a very long time, while some had never worn them. 
Thus, the Moscow Metro during the coronavirus was no longer a representation of Moscow's overall cultural diversity, but a reflection of the attitudes of city residents toward the coronavirus and the need to use means of protection against it. This added a new criterion for categorizing passengers:

A week ago, I would have had a greater sense of danger from people who put a medical mask. <. . > If they're wearing a mask, they're probably sick, and they put it on to avoid infecting people. This way of thinking is in the first place, and not vice versa.

(Man, 29 years old)

I think people who are without gloves, masks are more dangerous than others. Not because they are next to me at a particular moment without a mask or without gloves. If they don't use a mask and gloves on the Metro now, they're not so careful in terms of safety, behavior in other situations either.

(Woman, 27 years old)

There is a reaction, not like towards some shahids, but some irritation. I understand that they [people in masks] are acting silly. <.. .> People aren't ashamed of anything anymore, one can even put on a deer mask, I don't know, they are wearing some strange faces.

(Woman, 29 years old)

In the cited quotations, we can see three completely different reactions of the informants to the same detail in the personal front of strangers on the Metro. The division of opinions here is closely connected with the attitude of the passengers of the need to wear a mask. A young man who is suspicious of people wearing masks started wearing a mask in transportation after a sharp increase in the number of people getting infected. The second quote, on the contrary, belongs to a young woman who, at the time of the interview, was already very actively following all the recommended hygienic safety measures, so her attitude toward people wearing masks is rather positive and trusting. The third quote reflects the opinion of a person who has already clearly defined her attitude to the use of masks: her opinion is negative, so her emotions toward people wearing masks correspond.

Masks on par with gender and age attributes of the personal front have become a new, relevant criterion for public transport users to categorize strangers in the Metro. These examples show how issues and criteria intervene in the process of categorizing people on the Metro, and whose significance is high for the everyday life of the citizen during the pandemic as a whole, not just as Metro users. Since the wearing of masks was not yet mandatory during the "self-isolation regime", there was still discussion about the necessity of their use because a clear attitude toward masks had not yet emerged in public discourse. Therefore, the categorization of passengers based on an assessment of the appropriateness of their use of masks during this period belongs to the category of specific others rather than the stigmatized. On the other hand, it was the experience of 
everyday-travel on public transport and the opportunity to interact with people taking different precautions against the virus that contributed to the formation of attitudes toward the virus among informants, which then spread beyond the Metro. This is how the Metro and its passengers mutually influence each other, as other researchers have also indicated (Lindelöw, 2018).

\section{Stigmatized Others}

The categorization of the "stigmatized others" type occurs on the same grounds as in the previous type, that is, differences in personal front and the adherence to situational proprieties. Features of the personal front and ways of violating situational proprieties, based on which the categorization occurs, may even coincide. Nevertheless, what distinguishes stigmatized others from specific others is the degree to which their otherness is manifested and the moral assessment associated with it. In the case of stigmatized others, their otherness becomes a reason for trying to avoid being in the same gathering with them, and for being suspicious and hostile toward them.

With the onset of the "self-isolation regime", the same Metro passengers who were considered stigmatized even before the pandemic became more visible in the emptied Metro, leading to an even greater stigmatization. A stranger's ethnicity on the Metro became the basis for stigmatization more often. A new reason for categorizing a passenger as a "stigmatized other" was the failure to follow new hygiene recommendations, especially the lack of respect for distance which was previously quite common.

\section{PRACTICES OF CATEGORIZING STIGMATIZED OTHERS BEFORE THE CORONAVIRUS PANDEMIC}

A strong, unpleasant smell or very dirty clothes can become grounds for categorizing a passenger as a stigmatized other in the Metro. Although similar characteristics are attributed to specific others, here we are talking about a much stronger and more contrasting manifestation of uncleanliness which may make them not enter a crowded Metro car and wait for the next train. While passengers are willing to be tolerant or simply permissive toward many cultural differences, some things they do find difficult to accept are different manifestations of impurity, which tends to force them to adjust their behavior, prompting them to distance themselves, Such distancing, in turn, can be interpreted as a violation of civil inattention:

If I see homeless people in the metro with a bunch of their stuff, especially if it has a bad smell, I will probably inform the driver. I understand that, unfortunately, there is no complete system of some kind of help for these people, they're just dropped off. $<\ldots .>$ it happens more or less humanely. $<\ldots>[$ W] ith all due respect $<\ldots>$ I sincerely sympathize with these people. However, I sympathize with other people too.

(Man, 31 years old) 
This emphasis on purity is consistent with M. Douglas's conception (1966): by pointing to the "unclean", people categorize others, dividing participants in the gathering not just into the "understandable" and "incomprehensible", but singling out those who can harm the social order. Of course, the categorization of such passengers includes the determination of their socioeconomic status, which usually places them at the very bottom of the social hierarchy.

Another category of strangers who could be categorized as stigmatized others is ethnically different passengers. Despite the fact that such users of public transport is a category that received sufficient attention from both the media and the city authorities before the pandemic, ethnically different passengers in the Metro were not perceived as stigmatized others if they, like others, followed situational proprieties. They may well have blended in with the general passenger flow since their presence in the Moscow Metro is habitual. However, in a separate discussion of negative emotions in the Metro or potential threats, it is very likely that this particular category of passengers becomes the subject of attention. E. Goffman in Stigma explains the reasons for this as follows: "Typically, we do not become aware that we have made these demands or aware of what they are until an active question arises as to whether or not they will be fulfilled. It is then that we are likely to realize that all along we had been making certain assumptions as to what the individual before us ought to be" (1963: 2).

Frequently, at the moment of the conversation focused on the problems in the Metro, the otherness of the ethnically different passengers is actualized and problematized, which is expressed in the reproduction of stereotypes in relation to them. This category of passengers is not classified as a specific type as it is stigmatized in the public discourse, and a strong negative moral evaluation is attributed to it.

The informants' comments about ethnically-different passengers are primarily concerned with their violations of situational proprieties (rather than their personal front), especially related to sound, such as the loudness of conversations, the sounds of an unfamiliar language that irritate, or the general noisy behavior that intensifies in company:

[R] ussians are just a little quieter, and the fellows who come here, they are a little louder, more emotional, maybe, and somehow they just manage to draw attention to themselves a little more often. $<\ldots .>$ They discuss something very loudly, waving their hands somehow. I can't even describe. < . .> I don't know. Just in the metro, if someone catches your attention, when you look closely you understand that this person is a migrant.

(Man, 32 years old)

I think it happened to anyone, that guys from the Caucasian republics often stare at the passengers of the car, maybe discussing them, maybe not, because they discuss people not in Russian. This is also unpleasant, although I don't know, maybe they are talking about their own stuff and just looking around.

(Woman, 27 years old) 
It is clear from the quotations that the requirement of following situational proprieties is higher for this category of passengers than for all others. Unfamiliar speech with a glance become a violation of civil inattention even when the person admits that they are not sure whether they are the object of discussion at that moment. In these quotations, the reference to ethnically-different passengers is combined with references to more general categories, for example, when comparing "Russians" and "migrants"/"newcomers".

Thus, the behavior of a certain ethnically different passenger turns out to be less significant than the informant's perceptions of the typical features for this ethnicity. Their stigmatization which occurs due to the fact that certain cultural meanings are correlated with this category of people is related to this. Some ethnicities are connected with attributes of low socio-economic status and criminality: the passengers from other ethnic groups, even in the cited quotations, are mentioned together with other "newcomers" (ethnically similar), a category of people with low income and low social status. Much less frequently, but still another form of expression of otherness on their part is mentioned, like smells which are perceived by the informants as smells of an "unclean", of an "alien" cuisine, or, in the case of couriers, simply food.

\section{PRACTICES OF CATEGORIZING STIGMATIZED OTHERS DURING THE "SELF-ISOLATION REGIME"}

By erasing the former grounds for identifying specific others on the basis of a personal front, changes in everyday life have increased the cultural gap with the stigmatized others:

Yes, marginalized people have appeared, some sick people who walk and talk to themselves or to others and come up with some strange phrases. For example: 'If you do not have a family, then give birth from me.' Some of them are just jerks, there are really a lot of them emerged.

(Woman, 29 years old)

Then, stigmatized others who previously might have dissolved into the crowd and were more likely not to be in bodily contact with informants became more visible. At the same time, it became much easier for Metro passengers to avoid interacting with these people when necessary, because they had a lot of room to move around.

During the pandemic, the category of ethnically-different passengers acquired a special status: at the end of February 2020, the mayor of Moscow announced the need to "monitor those arriving from China" and "conduct raids" on public transport (Sobyanin, 2020c). Thus, there was an increased focus on all those people whose personal front allows others to categorize them as people who came from Asian countries, which could turn them into stigmatized others as written about in some media (Kravtsova, Lohov; 2020). However, based on the collected interviews, we cannot speak about the unambiguous assigning of ethnically-different passengers to stigmatized others after the pandemic began; informants never spoke about the Chinese as a potential source of infection. Due 
to the fact that information began to emerge quite quickly that it was possible to contract the coronavirus asymptomatically and not even know about it, additional attention as well as suspicion of passengers turned out to be directed more or less equally to all participants in the interaction.

At the same time, ethnicity during the self-isolation regime remained a signal of the possibility of other problems such as violence or theft. Coronavirus restrictions, according to informants, put large numbers of people out of work. Consequently, passengers became fearful that many were in such a desperate situation that they were willing to do all sorts of things.

An element of situational proprieties, such as keeping one's distance, became a criterion for classifying other people as stigmatized after the outbreak of the pandemic. The reduction in the number of people on the Metro made it easier to follow the rule of civil inattention, since there were far fewer people participating in gatherings. It also made it possible to keep a distance of 1.5 meters, which was difficult in a thick passenger flow. It is noteworthy that Metro users got used to this new order of interaction fairly quickly, although it changed their usual daily routine characterized by close bodily contact quite dramatically.

Although passengers were largely forced to keep their distance during the self-isolation regime by the authorities, they already sought to distance themselves from others due to the nature of illness and the medical recommendations disseminated by the media. It was the rule of keeping distance, more than others, that was accepted by Metro users, and its violation was the basis for categorizing passengers as stigmatized others. For example, not everyone was willing to wear a mask or gloves themselves, and not everyone approved when others did, but the need to maintain distance became a consensus point for my informants. This may be due to the fact that distancing even before the pandemic was part of maintaining polite inattention. Following this rule required less effort, and was less likely to transform the usual course of interactions.

At the beginning of the pandemic when masks and gloves were not yet compulsory, the violation of distance between passengers was perceived as a serious violation of situational proprieties. This may also be due to the fact that distance compliance was the first measure that was institutionally declared mandatory, and a fine was imposed for its violation.

It is interesting that in the eyes of the informants, the perpetrators of the new situational proprieties, namely the observance of the distance, were often ethnically-different passengers. This may be, for example, due to the fact that by categorizing these people as ethnically different, some of the informants distinguish them from the general picture of disciplined workers who continued to use the Metro:

Who draws my attention ... Guys from our southern republics, especially now, when I go to work during the epidemic. Not everyone of course, but the majority try to keep social distance, for instance, and these guys . . . . . T They don't try to keep the distance at all. They sit in a crowd near people, even if no one is around. 
Again, they don't seem to be doing anything so threatening, but this kind of demonstrative violation of the norms that everyone's talking about is scary.

(Woman, 27 years old)

The changes in the perception of this category of passengers are rather ambiguous. On the one hand, one cannot speak of a sharp increase in xenophobia toward people of other ethnicities, which the media had predicted. On the other hand, additional grounds for their stigmatization appeared. Not only were violations of sanitary and hygienic norms attributed to them, but also concerns related to the safety of Metro passengers were voiced. The absence of the imposition of new meanings related to the virus in this category, but the reinforcement of beliefs concerning the socioeconomic situation of this group may testify to the strength of attitudes toward migrants anchored in public discourse.

Therefore, the announcement of the self-isolation regime and the introduction of digital passes reinforced the informants' perception of people in the Metro as a rather homogeneous passenger population, but the explanation for this had new grounds. At the same time, the otherness in the personal front of passengers who were out of the category of co-present strangers became more noticeable. Following the transformation of the epidemiological situation and the emergence of new sanitary and hygienic recommendations, previous categorization criteria (for example, indication of socioeconomic status) for some categories of passengers faded into the background, and for others, on the contrary, strengthened.

If, as has already been said, not many details of the personal front could affect the interaction between the participants of the gathering, the situational proprieties in the Metro imposed serious restrictions on the individual. Before the pandemic, they were largely built around general norms of behavior in public places that formed civil inattention: no noise, no pushing, offering seats to the elderly, standing on the escalator to the right and passing to the left, taking off one's backpack, and so on. However, if only these proprieties were violated, depending on the type of passenger (non-specific, specific, stigmatized) the consequences were different. The intolerance for violating situational proprieties from co-presenters to stigmatized strangers increased. What may have received no attention in the actions of the co-present stranger, the other may have become a reason for focused interaction in relation to the stigmatized, and a violation of civil inattention that is atypical of Metro interactions. During the self-isolation regime, the observance of distance, which had not been realized before and was often violated in the crowd, became the main situational propriety and the criterion for distinguishing the stigmatized type of passengers. At the same time, the ambiguity of the interpretation of passenger behavior and the clear grounds for distinguishing a specific type disappeared. 


\section{Conclusion}

The article analyzed the transformations that occurred in the categorization practices of Moscow Metro passengers. These transformations are a reflection of the changes in the everyday life of Moscow residents during the pandemic. Based on the analyzed data, one can observe how the former grounds for the categorization of Metro users (personal front features reflecting socioeconomic, demographic, or cultural differences) ceased to be so significant. The social diversity of Metro passengers with the ability to distinguish both mere "co-present strangers" and "specific/stigmatized others" has become more homogeneous due to officially introduced measures and passenger self-organization. Those who had previously belonged to the category of the "stigmatized others" became even more stigmatized, but everyone else turned into "non-specific strangers".

These results demonstrate the productivity of the analysis of everyday categorization and the distinction between the three types of strangers that I suggested in the article. The transformation of categorization due to the introduction of "self-isolation regime", as we have seen, had different consequences for Metro passengers depending on which of the three types they belonged to. My study thus shows how sociocultural differences and categorization practices can influence each other, and how important it is to consider them in combination.

This categorization is the basis of interactions between strangers in public spaces. Therefore, its study should be the starting point for further research into other everyday practices; for example, in the case of the pandemic, one might consider, despite the presence of several types of others, how it is possible to collectively maintain public health through joint adherence to new hygiene rules (keeping a social distance, and wearing masks), which still continue to apply, including the Metro.

\section{References}

Adey P., Bissell D., McCormack D., Merriman P. (2012) Profiling the Passenger: Mobilities, Identities, Embodiments. Cultural Geographies, vol. 19, no 2, pp. 169-193.

Anderson E. (2004) The Cosmopolitan Canopy. The ANNALS of the American Academy of Political and Social Science, vol. 595, no 1, pp. 14-31.

Augé M. (1995) Non-places: Introduction to an Anthropology of Supermodernity, London: Verso.

Augé M. (2002) In the Metro, Minneapolis: University of Minnesota Press.

Bærenholdt J. O. (2013) Governmobility: The Powers of Mobility. Mobilities, vol. 8, no 1, pp. 20-34.

Banister D. (2011) Cities, Mobility and Climate Change. Journal of Transport Geography, vol. 19, no 6, pp. 1538-1546.

Bissell D. (2016) Micropolitics of Mobility: Public Transport Commuting and Everyday Encounters with Forces of Enablement and Constraint. Annals of the Association of American Geographers, vol. 106, no 2, pp. 394-403. 
Cawood I., Upton Ch. (2013) "Divine Providence": Birmingham and the Cholera Pandemic of 1832. Journal of Urban History, vol. 39, pp. 1106-1124.

Cresswell T. (2006) On the Move: Mobility in the Modern Western World, London: Routledge.

Darling J., Wilson H. (2016) Encountering the City: Urban Encounters from Accra to New York, London: Routledge.

Davis M., Levine S. (1967) Toward a Sociology of Public Transit. Social Problems, vol. 15, no 1 , pp. 84-91.

Douglas M. (1966) Purity and Danger: An Analysis of the Concepts of Pollution and Taboo, London: Routledge \& Kegan Paul.

Ferreira C., Sá M., Martins J., Serpa S. (2020) The COVID-19 Contagion-Pandemic Dyad: A View from Social Sciences. Societies, vol. 10, no 4, art. 77.

Goffman E. (1963) Stigma: Notes on the Management of Spoiled Identity, Englewood Cliffs: Prentice-Hall.

Goffman E. (1966) Behavior in Public Places: Notes on the Social Organization of Gatherings, New York: Free Press.

Goffman E. (1983) The Interaction Order. American Sociological Review, vol. 48, no 1, pp. $1-17$.

Ingvardson J.B., Nielsen O.A. (2019) The Relationship between Norms, Satisfaction and Public Transport Use: A Comparison across Six European Cities Using Structural Equation Modelling. Transportation Research Part A: Policy and Practice, vol. 126, pp. $37-57$.

Interfax (2020) Masochno-perchatochnyj rezhim v Moskve sohranitsya [Mask-andGlove Regime in Moscow will Remain]. Available at: https://www.interfax.ru/moscow/712328 (accessed 12 December 2021).

Jayyusi L. (1984) Categorization and the Moral Order, New York: Routledge \& K. Paul.

Jayyusi L. (1991) Values and Moral Judgment: Communicative Praxis as Moral Order. Ethnomethodology and the Human Sciences (ed. G. Button), Cambridge: Cambridge University Press, pp. 227-251.

Jensen O.B. (2006) "Facework", Flow and the City: Simmel, Goffman, and Mobility in the Contemporary City. Mobilities, vol. 1, no 2, pp. 143-165.

Kahlin L., Tykesson I. (2016) Identity Attribution and Resistance among Swedish-Speaking Call Center Workers in Moldova. Discourse Studies, vol. 18, no 1, pp. 87-105.

Kravtsova I., Lokhov P. (2020) "Na menya ozirayutsya, kak na prokazhennogo" ["They Look Back at Me Like I'm a Leper"]. Available at: https://meduza.io/feature/2020/02/21/ na-menya-ozirayutsya-kak-na-prokazhennogo (accessed 12 December 2021).

Koefoed L. M. M., Christensen M. D., Simonsen K. (2017) Mobile Encounters: Bus 5A as a Cross-cultural Meeting Place. Mobilities, vol. 12, no 5, pp. 726-739.

Lindelöw D. (2018) Running to Stand Still: The Role of Travel Time in Transportation Planning, Gothenburg: SWECO.

Lofland J. (1969) Deviance and Identity, Englewood Cliffs: Prentice-Hall. 
Lofland L. H. (1973) A World of Strangers: Order and Action in Urban Public Space, New York: Basic Books.

Lofland L. H. (1998) The Public Realm: Exploring the City's Quintessential Social Territory, Hawthorne: Aldine de Gruyter.

Lucas K. (2006) Providing Transport for Social Inclusion within a Framework of Environmental Justice in the UK. Transportation Research Part A: Policy and Practice, vol. 40, no 10, pp. 801-809.

Maines D.R. (1979) Ecological and Negotiation Processes in New York Subways. Journal of Social Psychology, vol. 108, no 1, pp. 29-36.

Markak V., Mondada L. (2012) Embodied Orientations towards Co-participants in Multinational Meetings. Discourse Studies, vol. 14, no 1, pp. 31-52.

Matthewman S., Huppatz K. (2020) A Sociology of COVID-19. Journal of Sociology, vol. 56, no 4, pp. 675-683.

McCauley B. (2003) Consider the Cure. Journal of Urban History, vol. 29, no 6, pp. 794801.

McKinlay A., McVittie C. (2011) "This is jist my life noo": Marriage, Children and Choice in a Scottish Fishing Community. Discourse \& Society, vol. 22, no 2, pp. 175-189.

Meduza (2020a) Kak v Moskve snizilos' ispol'zovanie taksi i obshchestvennogo transporta [How Moscow has Reduced the Use of Taxi and Public Transport]. Available at: https://meduza.io/short/2020/o4/o2/kak-v-moskve-snizilos-ispolzovanie-taksi-iobschestvennogo-transporta (accessed 12 December 2021).

Meduza (2020b) VOZ dolgo govorila, chto maski ne nado nosit' vsem podryad. A teper' govorit, chto, mozhet, i nado. Tak nosit' ili net? I esli da, to kak pravil'no? [WHO Said for a Long Time that Masks should not be Worn by Everyone. But Now It Says that Maybe they Should. Should I Wear Them or Not? And if So, What's the Right Way to Do It?]. Available at: https://meduza.io/cards/davayte-raz-i-navsegda-nuzhno-vsetaki-nosit-maski-vo-vremya-epidemii-ili-net-a-srochno-delat-ih-doma-samomu (accessed 12 December 2021).

Mondada L., Bänninger J., Bouaouina S., Camus L., Gauthier G., Hänggi P., Koda M., Svensson H., Tekin B. (2020) Human Sociality in the Times of the COVID-19 Pandemic: A Systematic Examination of Change in Greetings. Journal of Sociolinguistics, vol. 24, no 4, pp. 441-468.

Moore M., Gould Ph., Keary B. (2003) Global Urbanization and Impact on Health. International Journal of Hygiene and Environmental Health, vol. 206, no 4-5, pp. 269-278.

Ocejo R.E., Tonnelat S. (2014) Subway Diaries: How People Experience and Practice Riding the Train. Ethnography, vol. 15, no 4, pp. 493-515.

Oslon A. (ed.) (2021) Sociologiya pandemii. Proekt koronaFOM [The Sociology of the Pandemic. CoronaFOM Project], Moscow: Institute of Public Opinion Foundation.

Sacks H. (1972a) An Initial Investigation of the Usability of Conversational Data for Doing Sociology. Studies in Social Interaction (ed. D. Sudnow), New York: Free Press, pp. 31-74. 
Sacks H. (1972b) On the Analyzability of Stories by Children. Directions in Sociolinguistics: The Ethnography of Communication (eds. J. J. Gumperz, D. Hymes), New York: Rinehart \& Winston, pp. 325-345.

Sager T. (2016) The Ethics of Mobilities: Rethinking Place, Exclusion, Freedom and Environment, London: Routledge.

Snowden F. (2002) Naples in the Time of Cholera, 1884-1911, Cambridge: Cambridge University Press.

Sobyanin S. (2020a) Vozvrashchenie k normal'noj zhizni. Otmena samoizolyacii i propuskov [A Return to Normalcy: Abolition of Self-isolation and Omissions]. Available at: https://www.sobyanin.ru/otmena-samoizolyatsii-i-propuskov (accessed 21 July 2021).

Sobyanin S. (2020b) Koronavirus. Obrashchenie k starshemu pokoleniyu. Mery podderzhki semej s det'mi [Coronavirus. Appeal to the Older Generation. Support Measures for Families with cCildren]. Available at: https://www.sobyanin.ru/koronavirus-obraschenie-k-starshemu-pokoleniyu-i-semyam-s-detmi (accessed 12 December 2021).

Sobyanin S. (2020c) Koronavirus. Rasskazyvayu o dopolnitel'nyh merah po nedopushcheniyu proniknoveniya infekcii [Coronavirus. Tell You about Additional Measures to Prevent the Infection]. Available at: https://www.sobyanin.ru/koronavirus-merypo-nedopuscheniyu-proniknoveniya-infektsii (accessed 12 December 2021).

Stokoe E. (2010) "I’m not gonna hit a lady": Conversation Analysis, Membership Categorization and Men's Denials of Violence toward Women. Discourse \& Society, vol. 21, no 1 , pp. $59-82$.

Watson D.R. (1978) Categorization, Authorization and Blame - Negotiation in Conversation. Sociology, vol. 12, no 1, pp. 105-113.

Watson S. (2006) City Publics: The (Dis)enchantments of Urban Encounters, London: Routledge.

Welch T. F., Mishra S. (2013) A Measure of Equity for Public Transit Connectivity. Journal of Transport Geography, vol. 33, pp. 29-41.

Will C. (2020) "And breathe..."? The Sociology of Health and Illness in COVID-19 Time. Sociology of Health \& Illness, vol. 42, no 5, pp. 967-971.

Zaporozhets O. (2014) "Nastroit' gorod na svoyu volnu": metropoliten i upravlenie gorodskimi opytami ["Tuning the city to your own wave": Metropolitan and the Management of Urban Experiences]. Fashion Theory: Clothing, Body, Culture, vol. 33, pp. 143161.

\section{Влияние пандемии COVID-19 на практики категоризации пассажиров общественного транспорта: случай московского метрополитена}




\section{Ксения Шепетина}

Стажер-исследователь, лаборатория социальных исследований города, факультет городского и регионального развития, Национальный исследовательский университет «Высшая школа экономики» Адрес: ул. Мясницкая, д. 20, г. Москва, Российская Федерация 101000

E-mail: xenia.shepetina@gmail.com

В статье рассматриваются вопросы социальной категоризации и восприятия социального разнообразия пассажиров московского метро. Базируясь на теории Э. Гоффмана, я предполагаю, что взаимодействие между пассажирами основано на категоризации соотношении людьми внешнего вида и поведения друг друга с культурными ожиданиями. Категоризация позволяет сделать участников взаимодействия идентифицируемыми и понятными. В 2020 году маски и перчатки, социальное дистанцирование изменили процесс категоризации, напрямую затронув персональный фасад горожан и ситуационные приличия. Используя теоретические ресурсы Э. Гоффмана, Х. Сакса и современных городских исследователей, я сравниваю, как пассажиры московского метро узнавали и идентифицировали друг друга до пандемии коронавируса и во время режима самоизоляции, который был введен городскими властями весной 2020 года. Исследование строится вокруг трех основных типов Других, которые были разработаны как абдуктивные понятия: неспецифические, специфические и стигматизированные Другие. Я анализирую, как эти типы производятся ситуативно и в какой степени меняются, когда локализованный интеракционный порядок значительно трансформируется. С одной стороны, исследование направлено на подробное документирование уникальной социально-исторической ситуации, сложившейся на ранней стадии пандемии. С другой стороны, я использую ее как «естественный» эксперимент по нарушению фоновых ожиданий, который помогает выявить основные элементы временной и локальной специфики социального порядка.

Ключевые слова: социальная категоризация, повседневные взаимодействия, пандемия COVID-19, незнакомцы, метро, публичные места, Э. Гоффман 